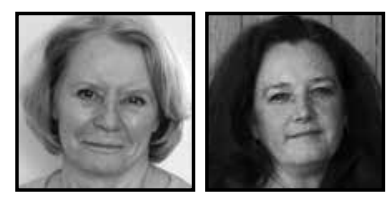

\title{
The Brilliance of Children
}

\section{Pat Cordeiro and Leslie Sevey, Rhode Island College}

\section{ABSTRACT}

Capturing and appreciating the brilliance of children as they share their unique insights has been a focus for researchers, educators, theorists, and humorists. Appreciating what that means and recapturing the effort may well be the challenge for the 21st century in education. Assigning children roles as co-collaborators in the educational process may be the only successful response to reversing the current path of education that makes children the objects of actions, and adults the agents of the action. Children's agency is derived from their parallel participation in learning, when their understanding is equally important to that of the teacher.

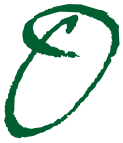

ver my desk at work there is a card with a quote from a short paper written by a fourth grade girl in an inner-city school. It reads: "A prediction without evidence is like a rumor."

This student was involved in a schoolwide initiative to develop critical thinking in young students; clearly she understood. In her clear and plain statement, she captures the essential element of deep analogical thinking, comparing a prediction, which she is trying to learn about, to a rumor, which she already knows about, because in her life as a fourth-grader, rumors may be rife. She incorporates in her simple sentence the essential element of attaching evidence to a claim, the foundation of democratic thinking. What an insightful, clear, and simple statement of a fundamental rule of documented critical thinking-you must have evidence to back up a claim (Hillocks, 2011) or you are not thinking critically. 
To me, this is so profound and so brilliant-a thought from a fourth grader who was given the opportunity to think and express her deep thinking on paper. I can only wonder, where did this go? I found it on a paper taped to the school principal's door. I copied it because I found it so compelling and astonishing for a young thinker. Was I the only one who noticed?

In another fourth grade inclusion class in an inner-city school, young students study geography. With the teacher's help, the students try to understand the difference between "natural" and "man-made" landmarks. They delineate the differences and list the criteria for classifying landforms and landmarks into one category or the other: "natural" landmarks are made of natural materials, no person has changed them, they were built by nature and without tools, they are notable and visited by people; people today come to visit them. "Man-made" landmarks may be natural landforms that have been changed by the works of man, their design may involve the use of tools, they may include more than natural materials, they are notable and visited by people; they have been created by people. The students in this class even consider monuments like Mount Rushmore as a "cross-over" landmark, first notable as a natural landmark, and then fitting the criteria for a man-made landmark.

And then a student asks, what about "animal-made" landmarks, like beaver dams, he says? How do we classify them-are they "natural" or "man-made"? And as the discussion proceeds, there is no easy answer to his brilliant question. No matter which criterion is used, "animal-made" landmarks stand alone-they are not made by nature or humans, they usually don't involve the use of tools so they don't qualify as "manmade" but they are made from natural materials and no human has made them, so they qualify as "natural;" people do come to visit them, photograph them, write about them, so they can be classified in both categories. What to do with this brilliant idea of a third category? This child's idea remains an enigma in the usual binary classification taught in geography lessons with classification schemes for young children, man-made versus natural - a brilliant and unresolvable find - a third category in a dichotomous scheme.

\section{Kids Say the Darndest Things}

No one listened to children better, documented their words more thoroughly, or enjoyed children's brilliant insights, literalness, and forthrightness, than Art Linkletter. No one asked better questions of children and honored them with attention, response, and respect than Art Linkletter. His early radio and television show, CBS House Party, ran 
for 14 years, while he interviewed 14,560 children (Linkletter, 1959). His books captured what Linkletter had learned about children over his many years of interaction with them, documented particularly in his summary book, The Secret World of Kids (1959).

Often he admired children's natural and naïve sense of humor: "What can your dad do around the house? -Well, once he tried to fix the car. What happened? -We had to get a new car." (p. 271). Or, "You have quite an imagination. Suppose a tiger came along and said he wanted to eat you. -I'd put him on TV because he could talk. What would you call the program? -Me and the Talking Tiger" (p. 111). Or this one, "One day on our House Party program I asked a six-year-old, 'What's your favorite toy?' And he brightly replied, 'Anything my big sister is playing with!'" (p. 95).

Often Linkletter was struck by children's innate sense of logic, their practicality, the brilliance of their direct thinking: "I asked the future lion tamer what he had to remember if he wanted to succeed with his four-footed friends. 'To stay away from their mouths,' he replied promptly, which summarized that profession very neatly" (p. 111). Or this one: "Five-year-old: 'I've got the smartest dog. All is to say is 'Are you coming in or aren't you?' and he either comes in or he doesn't" (p. 260).

Parents were invited to send in recordings of their children's sayings. Linkletter reported that, "the result was a flood of mail" (p. 260), including this gem:

My two-year-old, George, was playing in the yard when a cat came strolling by. He started to pet it, so I called out, 'George, that cat doesn't know you. He might scratch you.' He bent over, looked the cat straight in the eye and said, 'Cat, I'm George Blackwell.' (pp. 263-264)

Even at two years of age, children are speaking in logic.

Sometimes, Linkletter captured children's philosophical nature and their brilliant thinking about life. He writes:

Some have remarkable insight. The other day I asked a young lady of six to describe her conscience for me. Her answer came out in a rush, with no time for punctuation: "It's a gray ghost inside you with a friendly face but it stops smiling when your nerves begin to write a note to it when you want to do something bad and when the ghost sees this bad note he gets very angry and yells 'Stop!'” (p. 142) 
Linkletter notes that it's not possible for him to pick out his favorite example of children's thinking, but comments: "I think the one-word answer that impressed me the most, though, in this atomic age, came from a kid who thought for a moment when I asked him what he wanted to be when he grew up and finally said, 'Alive'"' (p. 284).

He recounts an interview with "a darling little girl whose shy answer to a question summed up for me all the magic and freshness of the secret world of kids. 'Have you ever been in love?' I asked her. 'No,' she said, 'but I've been in like.'" Linkletter notes, "Maybe that isn't my all-time favorite. But it'll do until a better one comes along" (p. 284).

Linkletter saw himself as an "incurable optimist" and thought that, "children are just about the most wonderful gadgets ever invented" (p. 285). He notes that one of his purposes was

to open up a few channels of communication between the weary world of adults and the Secret World of Kids. To enjoy a child, you must understand him. To understand him, you must communicate with him. What I've been trying to put on paper here is a blueprint for understanding and enjoying kids. (pp. 285-286)

He hopes that parents will enjoy their kids: "If once a day, for five seconds, you stop and consider what a fantastic privilege it is to bring life into the world and help it grow, I think you'll be a better parent - and a better person" (p. 286). Shouldn't this admonition apply to schools and teachers as well?

\section{Gareth Mathews and Childhood Philosophers}

A scholar, Gareth Mathews, was also documenting children's thinking and analyzing the brilliance of their words through a philosophic lens in his two books $(1980,1994)$ on remarkable early childhood thinking. In his first book, Matthews notes that, as a college professor, he found himself "worrying about how to teach introductory courses in philosophy to college students" (1980, p. vii). He notes: "It occurred to me that my task... was to reintroduce my students to an activity that they had once enjoyed and found natural, but that they had been socialized to abandon" (p. vii). What follows in this first book are nine short and succinct chapters documenting philosophic thinking in very young children, gathered by Matthews and others who he calls, "simply people who like children" (p. vii). 
Six-year-old Tim speculates on whether we can really know reality: "Papa, how can we be sure that everything is not a dream?" (p. 1). Four-year-old John takes his first plane ride and says, rather relieved, "Things don't really get smaller up there" (p. 4). Five-yearold David worries about whether apples are alive, deciding that it is alive when it's on the ground, but not when it's brought into the house (p. 6); seven-year-old Michael ponders whether the universe is infinite: "It's nice to know you're here... It is not nice to know about nothing. I hope [the universe] doesn't go on forever because it's obvious it can't be anywhere" (p. 35); six-year-old John notes that while he has body parts that he calls "his arms, his head,' he also has possessions that he calls 'his toys'. He wonders: "Which part of me is really me?" (p. 86).

For each example he re-creates, Matthews discusses the deeper philosophic questions behind the childish words, invoking philosophic and psychological theorists, comparing the children's ideas to larger and more well-discussed ideas, and always maintaining a stance of wonder toward the brilliance of what children think and say. Four-year-old Sarah, Matthews' daughter, is concerned about how the family cat, Fluffy, caught fleas. Matthews (1994) explains that fleas jump from one cat to another, and to another and so on, till they reach Fluffy. Sarah pauses and responds: "But Daddy... it can't go on and on like that forever, the only thing that goes on and on like that forever is numbers!" (p. 1). Luckily, Matthews (1980) is there to capture and reflect on the moment. He notes that puzzling over a new idea is "quintessentially philosophical" (p. 2) and finds that "Puzzlement and wonder are closely related," an idea he supports by turning to the philosopher, Bertrand Russell, who writes that philosophy "has at least the power of asking questions which increase the interest of the world and show the strangeness and wonder lying just below the surface even in the commonest things of daily life" (Russell, in Matthews, p. 2).

\section{How to Foster Brilliance-Or Can We?}

The question for education of today's and future young children becomes, How can we accommodate children's brilliant thinking and still complete the curriculum? Or more to the point, do we have time for children's brilliant thinking?

Several years ago, the late Australian educator, Garth Boomer (1989), gave a talk in which he addressed questions of best practices in education. He entitled his talk, "Literacy: The Epic Challenge Beyond Progressivism" and defined progressive teachers as ones who are "boundary riders," who "have chosen to teach at the edge of your 
understandings rather than to operate from safe and stable ground. You are modern teachers, progressive teachers, enquiring teachers. You anticipate discovery" (p. 1). He then goes on to define the characteristics of such teachers, beginning with "caring" that is "shown by careful teacher listening and response"; and is "individual oriented/ experience based;" he notes: "Each child is valued for his/her uniqueness. The child's expression of personal meaning is encouraged and rewarded as having intrinsic worth because of its authenticity" (p. 3).

As he continues to think about how to operationalize this, Boomer develops the idea of an "Epic Teacher." He notes: "Every now and then we are lucky to have a significant idea...essentially that we should deliberately teach each student how to read the curriculum (and the school)..." (p. 9). As he read Benjamin's (1983) "Understanding Brecht," he says the book "...took me further along the path of construing a new kind of postmodern, post-progressive teacher - the pragmatic radical - or, to be more evocative, the EPIC teacher" (Boomer, 1989, p. 9).

Drawing on the work of Bertolt Brecht in drama and theatre production, Boomer appropriates Brecht's creation of a new kind of theatre, and then Boomer applies this to teaching. Brecht reacted against the naturalistic theatre performance mode that was designed to surprise and woo an audience that had willingly suspended disbelief. In such theatre, the stage curtain draws the line between the staged performance and the audience, creating a "fourth wall," a wall that clearly and terminally separates the story from the viewers, a wall designed to preserve "the art that conceals art" (p. 9). Boomer notes that this naturalistic approach to theatre "...takes pains to hide its origins and its intentions. In a very direct sense, naturalistic theatre is charming" (p. 9).

And, of course, Boomer's logical conclusion is that

most progressive teachers are in the performative naturalistic mode...charming... The teacher is almost able to make his or her role invisible....The curriculum is almost like doing what comes naturally...Children are manipulated because the curriculum is... constructed and the teacher, in seeming not to design has palpable designs on the learners. (p. 9)

He concludes: "...the naturalistic classroom is unhealthy and essentially disempowering because it tends not to expose its own deep intentions and because it renders itself relatively immune to critique and transformation by the learners" (p. 9). 
So Boomer turns to Brecht and his Epic Theatre that cultivates what Brecht called "the alienation effect." The curtain between the play and the audience, what is called in theatre "the fourth wall," is pulled back, and the audience is asked to distance itself from the play and respond critically to the drama, to be "alienated" or "estranged" from the naturalness of the drama. In Brecht's plays, performers address the audience directly, stepping out in front of the curtain, breaking through the "fourth wall," requiring the audience to invoke belief, calling back the previously suspended belief and actualizing it, developing "a critical frame of mind" (p. 9), and becoming part of the "didactic" drama that is intentionally designed to effect change in the audience. Brecht's alienation effect is an intentional, "self-conscious," and didactic move to engage the audience fully and consciously in the problem at hand.

In light of Brecht's work, and to counterbalance a curriculum that might be merely entertaining, Boomer asks, "What would an Epic Teacher do?" (p. 10). Boomer's own words speak volumes and are worth repeating here:

An Epic Teacher, unlike the naturalistic teacher, would show the students that the curriculum is a construction designed to have certain effects on them. He or she would be continually taking students behind the set of his or her own theatre of performance, to see the scaffolding and the construction technologies. The Epic Teacher would assiduously cultivate an estrangement effect both with respect to his/her own views and with respect to the ideas and knowledge being promulgated. The students would be expected to be engaged and yet critical; moved and yet gently skeptical. The teacher would work dialectically to confront the values of the learners and also to confront and gently undermine him/herself. The classroom itself, as a community or sub-culture, would be rendered problematic. The teacher would be overtly didactic. Whereas the naturalistic teacher could manipulate by deceptions or "silences," the Epic Teacher would manipulate explicitly and self-consciously. (p. 10)

Early childhood education in the 21st century offers one avenue for beginning to not only actualize Boomer's vision of "a curtain pulled back" to reveal the curriculum, but also to provide a potential avenue for valuing and forefronting the brilliance of children. This theory is known in early childhood education in Reggio Amelia schools as "pedagogical documentation." 


\section{What Is Pedagogical Documentation?}

\section{Pulling Back the Curtain}

Pedagogical documentation has many purposes as described by the educators of Reggio Emilia, including: enhances the learning by the children; informs parents about their children's experiences in order to engage the families as a learning/teaching partner; serves as a basis for teacher research; and finally, provides evidence of children's learning and progress (Edwards, Gandini, \& Forman, 1995). Documentation often comprises teacher-written descriptions of projects, transcriptions by teachers of children's words, photographs, and samples of the children's symbolic representations, and is often posted in the classroom (Edwards, Gandini, \& Forman, 1995). Documentation can offer teachers and children the "opportunity to revisit, reflect, and interpret;" by supporting their memory so that they can "retrace their processes, to find confirmation or negation, and self-correct" (Rinaldi, 1998, p. 122).

The Reggio Emilia Approach is based on the belief that knowledge is constructed through relationships where the

central act of adults, is to activate, especially indirectly, the meaning-making competencies of children as the basis of all learning. They must try to capture the right moments, and then find the right approaches, for bringing together, into a fruitful dialogue, their meanings and interpretations with those of the children. (Malaguzzi, 1998, p. 81)

Intrigued by the use of pedagogical documentation to "enhance the learning by the children," as is stated above, Leslie studied the HOW. She wondered about how the children used the pedagogical documentation and what was the impact it might have on children's thinking processes, including memory, reflection, and critical thinking.

In the "Making Teaching Visible Project" (Project Zero, 2003), the research team identified features that capture the essence of documentation, which includes "sharing back with learners" (p. 17). They explain that

documentation contributes to children's own understanding of how they and others learn; it serves as a reminder of what goes on in the classroom, offering students an opportunity for reflection, for evaluation of other children's theories and hypotheses, and for self-assessment. (p. 17) 
Leslie found this to be true, that in order for the children to be able to reflect, the pedagogical documentation needs to be used as an external form of memory to first help them revisit the experience and reflect on what transpired. However, pedagogical documentation can also allow the teacher to support the learners in reflecting on their own strategies and even in some cases begin to think about their own decisions or thinking.

In other words the pedagogical documentation needs to be used as "bits and pieces along the way" (Sevey, 2010) rather than is often understood about documentation by teachers in the U.S. as "snapshots taken at the beginning and end of a process, and at isolated moments along the way" to be able to showcase the learning (Seidel, 2001, p. 308)

\section{Examples of documentation-"pulling back the curtain".}

In this exchange with $\mathrm{AL}$ the teacher was using documentation to support his memory of the previous experience with marbles and ramps. AL used the documentation to identify where he encountered a problem and explain the solution he devised.

Teacher: Does anyone remember this project here (referring to the photo on the documentation panel) that they were doing?

AL: I know - that was my group [the photo has refreshed his memory]

Teacher: Your group —ok AL what was happening in this picture?

AL: You can't really see the tube in the cup-the track is in the tube in there and if it's against the back of the cup the tube is in there and the marble goes down and it hits the track all the time [he explained the problem]

Teacher: So it hit the track on the front part - let's see you said that marble comes down here-and the tube is in there-it's hard to see because it's a clear tube-and the marble fell here-and you said it did what?

AL: It bounced back and then it hit the track.

Teacher: So did it bounce back out of the cup? No (AL shook his head no)—so you found a way to trap it in there so it didn't bounce back out (11/2/09 - week 6) (p. 62). [The teacher rephrases his explanation to demonstrate the solution]

In this example student IS reflected on what happened in a previous experience that was displayed on the documentation panel. The teacher referred to the experience and IS was able to explain why the marble was going slowly and considered the change her group made to its track. IS then shifted her thinking to be able to explain why the marble didn't land in the bucket. 
Teacher: IS come on up a minute-this looks like your group's plan here-this was your first try-what were you doing there?

IS: Umm-we were trying to drop the marble into the bucket-but I think it was going slow [problem encountered]

Teacher: Why do you think it was going slow? -looking at this picture-what made it go slow? — why did it go too slow?

IS: I think it was flat [student's definition of the problem]

Teacher: What was flat? Show me on there-you think that was too flat and the marble didn't go or it went really slow

IS: Yeah.

Teacher: (referring to the documentation) Then you changed your plan a little bit and I see you did something here-what were you doing here?

IS: We were making a bridge over the bucket and the marble went down and we tried it dropping into the cup.

Teacher: Did it work?

IS: Yes, I think.

Teacher: (referring to the photograph) You lifted it up a little bit and put it on the side of the bucket - then you changed it a little bit more_-now you've got something going up though-hmmm - did that work?

IS: No.

\section{Teacher: Why?}

IS: Because the marble can't go up and then drop into the bucket (11/9/09, week 7) (p. 69). [We can see the student is beginning to refine her understanding of the forces of gravity]

The kindergarten students were exploring the idea of chance versus strategy. They began with a game where they pulled items out of a bag and recorded what they got. On this day they were exploring the game of tic-tac-toe. In the whole group reflection after the experience, where documentation had been collected (photographs) and was being displayed, the teacher asked the students to reflect on the experience.

Mrs. R: So Ben you said you tricked Harper a couple of times, what does that mean?

Ben: I started out with one in the middle and then she put some here and I put one here. 
Mrs. R: So your strategy, I am using the word strategy and you used the word trick. You had a plan that you always wanted to put it in the middle. That's called a strategy. What's the difference between this game and the game you pulled things out of the bag?

C: You didn't know what you were going to get.

A: You couldn't look inside the bag. This game, tic-tac-toe, you could look.

Mrs. R: When you played that game you never knew what you would get and this game you could make a plan.

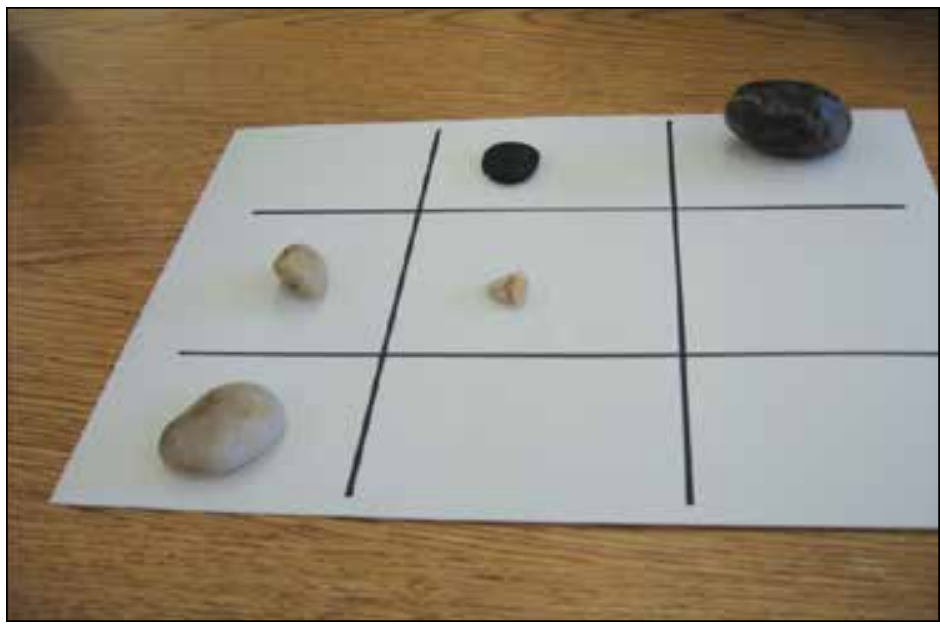

Fig. 1: Tic-tac-toe

The kindergarten students were continuing their exploration of the concept of chance versus strategy. The teacher provided a variety of games for the children to play as they developed their understandings of chance and strategy. On this day the teacher provided a game that was based on strategy but she did not define this for the students ahead of time, rather she asked them if they thought the game was based on chance or strategy.

Mrs. R explained the rules for the game "The Last Survivor": You will need to decide whether you will take one rock or two rocks for each turn. There are 13 rocks total. The person to take the last rock wins. 
She asked the students if they thought this game was chance, and was it fair? The teacher asked two children to come up to the front to demonstrate a practice round. After they completed the practice round she asked...

Mrs. R: Do you have an idea?

Bobby: The person who goes first always wins. There's thirteen, if someone has three people and two people on their side that's three. He took one, she took one, then she could win. It depends on how you take the rocks.

Ava: If you take one rock then it might mean that you could win.

Mrs. R: Each of you took two each time, Maddy and Bobby.

\section{Conclusion}

It is hard these days to find examples of how we might maximize children's brilliant thinking, either in schools or out; no one is doing quite what Linkletter and Matthews did as they documented children's thinking so thoroughly and with such optimism, admiration, respect, and reflection. True, there is a cable network program called "Seriously Funny Kids," on which moderator Heidi Klum plays the straight man to selected young comics with unique ideas. And an advertisement for an insurance company regularly features a man sitting at a low table with four kindergarteners, a different group each time, while the children express their ideas on a variety of philosophic questions, such as "Is fast better than slow?" Children's responses are charming, adult reaction is appropriate, but such current efforts all fall far short of earlier efforts to document and understand the ideas and brilliance of children's thinking.

Educators and psychologists, most notably, have listened closely to children's words, both spoken and written, with insightful and influential conclusions. Donaldson (1978) in "Children's Minds" observed and documented children's developing thinking and concluded:

By the time they come to school, all normal children show skill as thinkers and language users to a degree which must command our respect, so long as they are dealing with "real-life" meaningful situations in which they have purposes and intentions and in which they can recognize and respond to similar purposes and intentions in others....He is conscious of the outer world that he is dealing with and of his goals in that world. Then he cannot fail to be aware of himself as an agent in that world, coping with it. (p. 127) 
Paley's many books document various aspects of her kindergarteners' talk, play, and thinking. In her 1990, "The Boy Who Would Be a Helicopter," she notes:

... aside from all else we try to accomplish, we [teachers] have an awesome responsibility. We must become aware of the essential loneliness of each child. Our classrooms, at all levels, must look more like happy families and secure homes...the kind in which all family members can tell their private stories, knowing they will be listened to with affection and respect. (p. 148)

In her books, Gallas documents and analyzes children's learning and language development in her classroom. In her 2003 "Imagination and Literacy: A Teacher's Search for the Heart of Learning," she writes "...educators must reclaim, rename, and reimagine teaching and learning" (p. 165) and "Imagining new educational worlds is a project that would require us to throw aside so many assumptions about the world and the purposes of education" (p. 167).

These writers certainly do serve to preserve children's unique and thinking but they are few and far between, and far away from now. Today's view of children is often more interested in the content that children have acquired in their few years and the data that can be collected from testing them, than from the remarkable and notable instances of children's thinking and insight. I think most would agree that American education today is not equipped to accommodate much brilliant thinking, either in curricular design or day-to-day classroom scheduling. Government grants and agencies in many places have mandated curriculum, standards, and testing which all drive the dayto-day practice of classroom teachers. Gallas notes: "All my years in public education have rendered me unable to proceed - unable to imagine what schools would look like if imagination were recognized as the necessary center of learning and growth" (p. 167). Even 10 years ago, in her publication, education was moving farther and farther away from finding a place in schooling for children's thinking and imagining. She continues: "...the outcomes of such learning won't fit within the framework of 'measurable outcomes,' standardized tests, rubrics, programmed learning" (p. 168).

In company with Boomer, Gallas concludes:

The social alterations of such learning shift power and authority from the teacher alone to the teacher and students and that, above all, will provoke discomfort in those who most fear disorder, those who believe that disorder (talk, movement, laughter, joy?) is not present in serious learning environments, those who believe that disorder means loss of control and that loss of control is always dangerous. (p. 168) 
So the question becomes, "Is there any way to foster and grow the development of children's brilliance in today's classroom market?" We must begin with children themselves and their capacity for greatness, "the boundless potential that all our children represent" (Gallas, p. 169). In "Closely Observed Children," Michael Armstrong (1980) strives to understand children's understanding and notes that, "One way of beginning is to examine, with careful sympathy, the thought and action of the children who we ourselves are teaching" (p. 206).

And so we come full circle, returning back to notions of listening to children as the key to educational security, listening with respect and admiration, with curiosity and insight, and with humor and an open mind. We come back to Linkletter's (1959) attempt to create "a blueprint for understanding and enjoying kids" (pp. 285-286) after he spent so many years doing just that. We listen to Armstrong (1980) as he seeks to "draw attention to one particular feature of the early life of reason" (p. 206), a feature he sees as essential to intellectual growth: "That feature is the seriousness of purpose in children's thought and action: their high intent" (p. 206). Returning our focus to children, recapturing a sense of wonder at their unique thinking, "pulling back the curtain" and making them partners in their own learning, sharing authority and power, and listening very carefully to what children have to say, may shift education to a better place, a place where "our educational system is meant to serve the interests and well-being of children, rather than those of adults" (Gallas, 2003, p. 168). Perhaps we are still trying to understand Linkletter's (1959) attempts to "open up a few channels of communication between the weary world of adults and the Secret World of Kids" (p. 285). If so, perhaps there's still time to capture children's "seriousness of purpose, their high intent" (p. 206) and understand what it means. 


\section{References}

Armstrong, M. (1980). Closely observed children: The diary of a primary classroom. London: Verso

Benjamin, W. (1983). Understanding Brecht. Verso: London.

Boomer, G. (1989, July). Literacy: The epic challenge beyond progressivism. Paper presented at the Joint Australian Reading Association and Australian Association for the Teaching of English National Conference.

Donaldson, M. (1978). Children's minds. New York: W.W. Norton.

Edwards, C., Gandini, L., \& Forman, G. (Eds.). (1995). The hundred languages of children: The Reggio Emilia approach. Norwood, NJ: Ablex.

Gallas, K. (2003). Imagination and literacy: A teacher's search for the heart of learning. New York: Teachers College.

Hillocks, G. (2011). Teaching argument writing, grades 6-12: Supporting claims with relevant evidence and clear reasoning. Portmouth, $\mathrm{NH}$ : Heinemann.

Linkletter, A. (1959). The secret world of kids. New York: Bernard Geis Associates.

Malaguzzi, L. (1998). History, ideas, and basic philosophy. In C. Edwards, L. Gandini, \& G. Forman (Eds.), The hundred languages of children: The Reggio Emilia approach - Advanced reflections (2nd ed.) (49-98). Greenwich, CT: Ablex.
Matthews, G. (1980). Philosophy and the young child. Cambridge, MA: Harvard University Press.

Matthews, G. (1994). The philosophy of childhood. Cambridge, MA: Harvard University Press.

Paley, V. (1990). The boy who would be a helicopter: The uses of storytelling in the classroom. Cambridge, MA: Harvard University.

Project Zero. (2003). Making teaching visible: Documenting individual and group learning as professional development. Cambridge, MA: Harvard University.

Rinaldi, C. (1998). Projected curriculum constructed through documentation - progettazione. In C. Edwards, L. Gandini, \& G. Forman (Eds.), The hundred languages of children: The Reggio Emilia approach Advanced reflections (2nd ed.) (pp. 113-125). Greenwich, CT: Ablex.

Seidel, S. (2001). Understanding documentation starts at home. In C. Giudici, C. Rinaldi, \& M. Kreshevsky (Eds.), Making learning visible: Children as individual and group learners (pp. 304-311). Reggio Emilia, Italy: Reggio Children.

Sevey, L. (2010). The role of pedagogical documentation in developing young children's thinking processes. Unpublished dissertation. Rhode Island College, Providence, RI. 


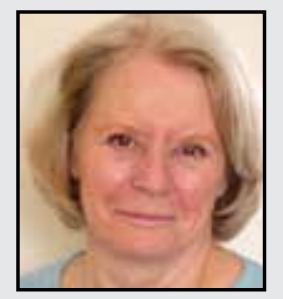

Pat Cordeiro is Professor and department chair in elementary education at Rhode Island College in Providence, Rhode Island. Her research interests and publications are in language and literacy, with a focus on children's writing. She was chair of the Elementary Section, served on the review board, and is currently on the editorial board of the journal Language Arts-all activities of the National Council of Teachers of English. She has been a reviewer for several journals and publishers. Her 25 years of teaching elementary school coupled with her more recent 21 years in teacher education have left her with more questions than answers about trends in today's schooling.

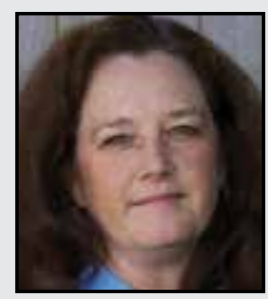

Leslie Sevey is an Assistant Professor in early childhood education at Rhode Island College in Providence, Rhode Island. Her research interests are focused around young children's thinking and reflection. Leslie has 15 years of experience in the early care and education workforce as an educator and administrator in addition to 12 years in teacher education. 